\title{
Primary angiosarcoma of the small intestine with metastasis to the liver: a case report and review of the literature
}

\author{
Qingqiang $\mathrm{Ni}^{1}$, Dong Shang ${ }^{1 *}$, Honghao Peng ${ }^{1,2}$, Manish Roy ${ }^{1,3}$, Guogang Liang ${ }^{1}$, Wei Bi ${ }^{1}$ and Xue Gao ${ }^{4}$
}

\begin{abstract}
Angiosarcoma is a rare disease with a poor prognosis; significantly, patients with intestinal angiosarcomas who survive over 1 year after diagnosis are extraordinarily rare. This article describes the case of a 33-year-old gentleman who presented with abdominal pain of 4 months duration, which had increased in severity 2 weeks prior to presentation. After a complicated diagnostic and therapeutic process, the diagnosis of primary angiosarcoma of the small intestine with metastasis to the liver was made by pathological and immunohistochemical examinations. We reviewed previous cases of angiosarcoma described in the English literature to determine their risk factors, diagnosis and treatment, and we found that angiosarcoma is extremely rare, especially in the small intestine. To the best of our knowledge, this may be the youngest case of primary angiosarcoma of the small intestine with metastasis to the liver reported in the English literature.
\end{abstract}

Keywords: Small intestine, Primary angiosarcoma, Hepatic metastasis

\section{Background}

Angiosarcomas, which account for only 1 to $2 \%$ of all soft tissue sarcomas, are rare malignant tumors of endothelial origin $[1,2]$. These tumors are usually found in the scalp and facial skin of elderly individuals, with a male preponderance [3]. Primary angiosarcoma of the small intestine is extremely rare; moreover, due to the difficulty of prompt and accurate diagnosis, its prognosis is very poor $[1,4]$. To the best of our knowledge, few cases of primary angiosarcoma of the small intestine have been reported in the English literature [5], especially primary angiosarcoma of the small intestine with metastasis to the liver in a young patient.

Here, we report a 33-year-old gentleman who presented with abdominal pain of 4 months duration, which worsened in the last 2 weeks prior to presentation.

\section{Case presentation}

A 33-year-old gentleman admitted to our hospital on 5 August 2011 presented with a 4-month history of pain

\footnotetext{
* Correspondence: tougao1971@163.com

'Department of General Surgery, First Affiliated Hospital, Dalian Medical University, Dalian, Liaoning 116011, P.R. China

Full list of author information is available at the end of the article
}

in the left lower quadrant of the abdomen, which had worsened in the last 2 weeks before presentation.

Four months ago, the patient began experiencing abdominal pain in the lower left quadrant without any apparent cause. The symptoms became increasingly aggravated during the last 2 weeks before presentation. The presenting symptoms included paroxysmal colic in the left lower quadrant of the abdomen, fever, nausea and vomiting. The patient also experienced fatigue and an $8 \mathrm{~kg}$ weight loss over the last 4 months. In a nearby local hospital, an abdominal plain film was obtained, which showed intestinal tympanites.

For further treatment, the patient came to our outpatient department and was admitted to the Department of Gastroenterology. A physical examination revealed a male patient with tenderness in the left lower abdominal region. There was no hepatomegaly or splenomegaly. Laboratory tests were performed, and the results were normal, including the levels of carcinoembryonic antigen and carbohydrate antigen 19-9. Computed tomography (CT) scans of the whole abdomen showed a significantly thickened intestinal wall located at the end of the jejunum and the proximal ileum, excessive ascites and a few enlarged lymph nodes in the abdomen (Figure 1). Contrast-enhanced CT 


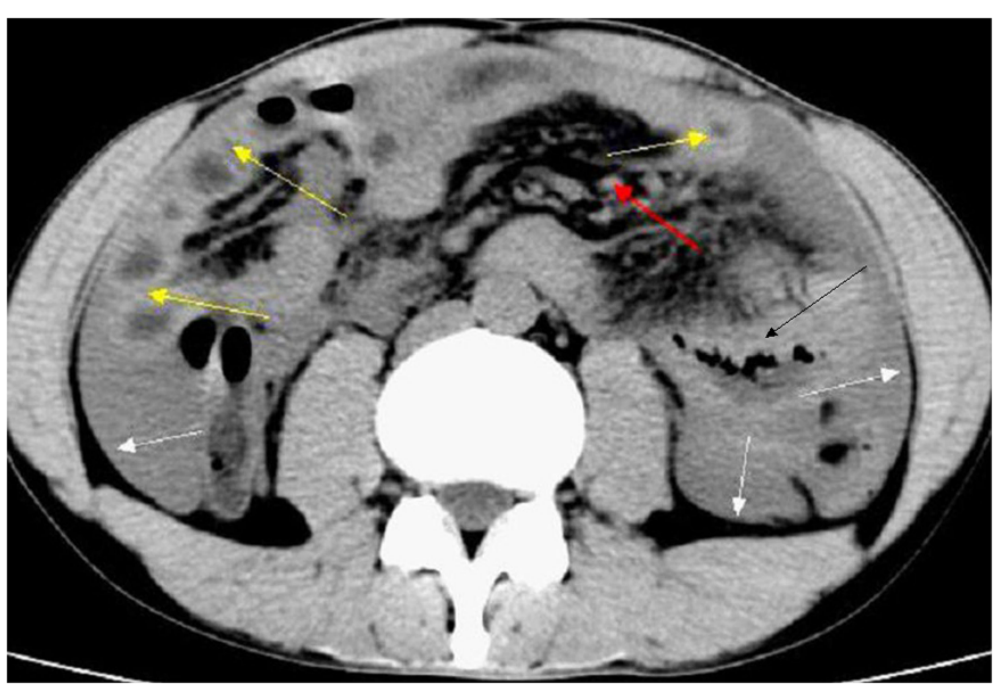

Figure 1 Computed tomography scans of the whole abdomen showed a significantly thickened intestinal wall (yellow arrows) located at the end of the jejunum and the proximal ileum, excessive ascites (white arrows), a few enlarged lymph nodes in the abdomen (red arrow) and the location of the primary angiosarcoma of the small intestine (black arrow).

scans showed different degrees of enhancement in the hepatic arterial phase (Figure 2).

An urgent general surgical consultation was required because of sudden severe aggravation of the abdominal pain. Abdominocentesis was performed, which showed a dark red fluid. The patient presented with peritonitis. Therefore, an emergency laparoscopic surgery was performed, which was later converted to a laparotomy following partial enterectomy. The operative findings included intra-abdominal bleeding of $1500 \mathrm{ml}$ and an oedematous small intestine. Additionally, the greater omentum was found adherent to the small intestinal mesentery in the left upper abdomen with inflammation and blood oozing from the small intestine. During surgical exploration, dozens of irregular nodules of various sizes were found scattered on the surface of the liver. In addition, a mass of approximately $5.0 \times 6.0 \mathrm{~cm}$ in size was found in the small intestine approximately $70 \mathrm{~cm}$ distal to the ligament of Treitz and was accompanied by an endoleak. During the operation, the tumor and the local mesentery of the small intestine were resected. Eight lymph nodes were examined, and two were found to be metastatic. On microscopic examination, vascular invasion of tumor tissue could be observed. The blood vessels of the tumor were abundant with tumor cells around them, and the tumor cells were arranged in a slit-shaped pattern (Figure 3). The immunohistochemistry results showed that the tumor cells were positive for CD31 and vimentin (Figure 4) and negative for CD34, actin, S-100, CD117 and CK56. Moreover, the Ki-67 proliferation index was less than $10 \%$ positive. On the basis of these findings, adenocarcinoma, intestinal tuberculosis, neuroendocrine tumor, malignant melanoma, Crohn's
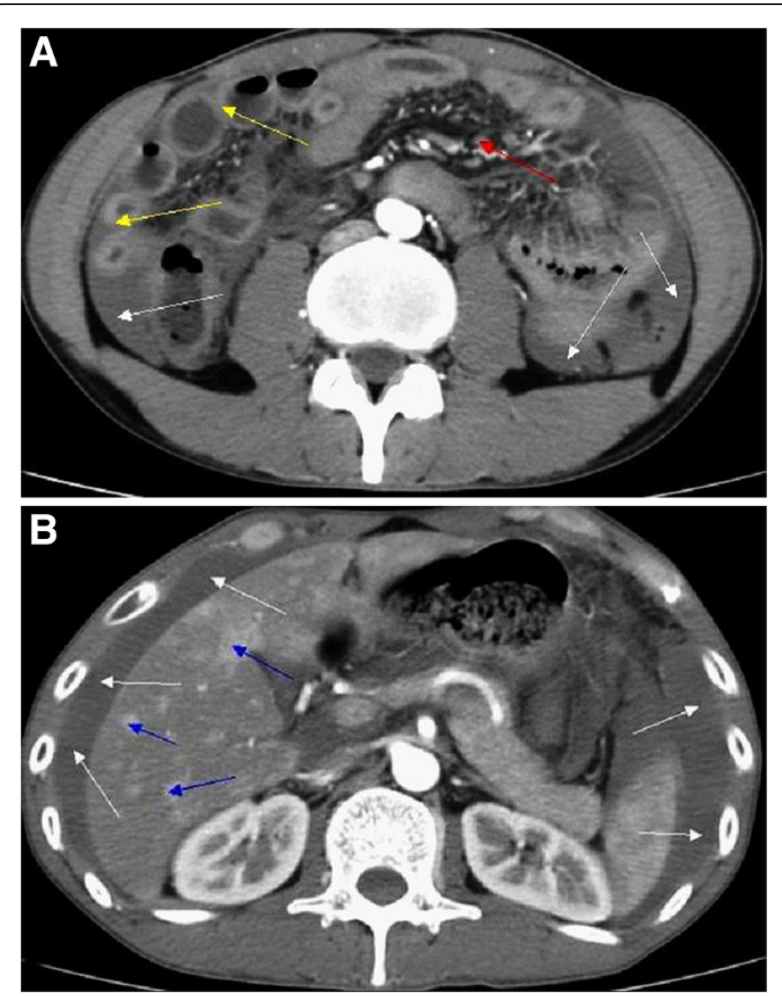

Figure 2 Enhanced computed tomography scan. (A) A significantly thickened intestinal wall (yellow arrows) located in the end of the jejunum and the proximal ileum, excessive ascites (white arrows) and a few enlarged lymph nodes in the abdomen

(red arrow). (B) Different degrees of enhancement were noted in the hepatic arterial phase (blue arrows). 

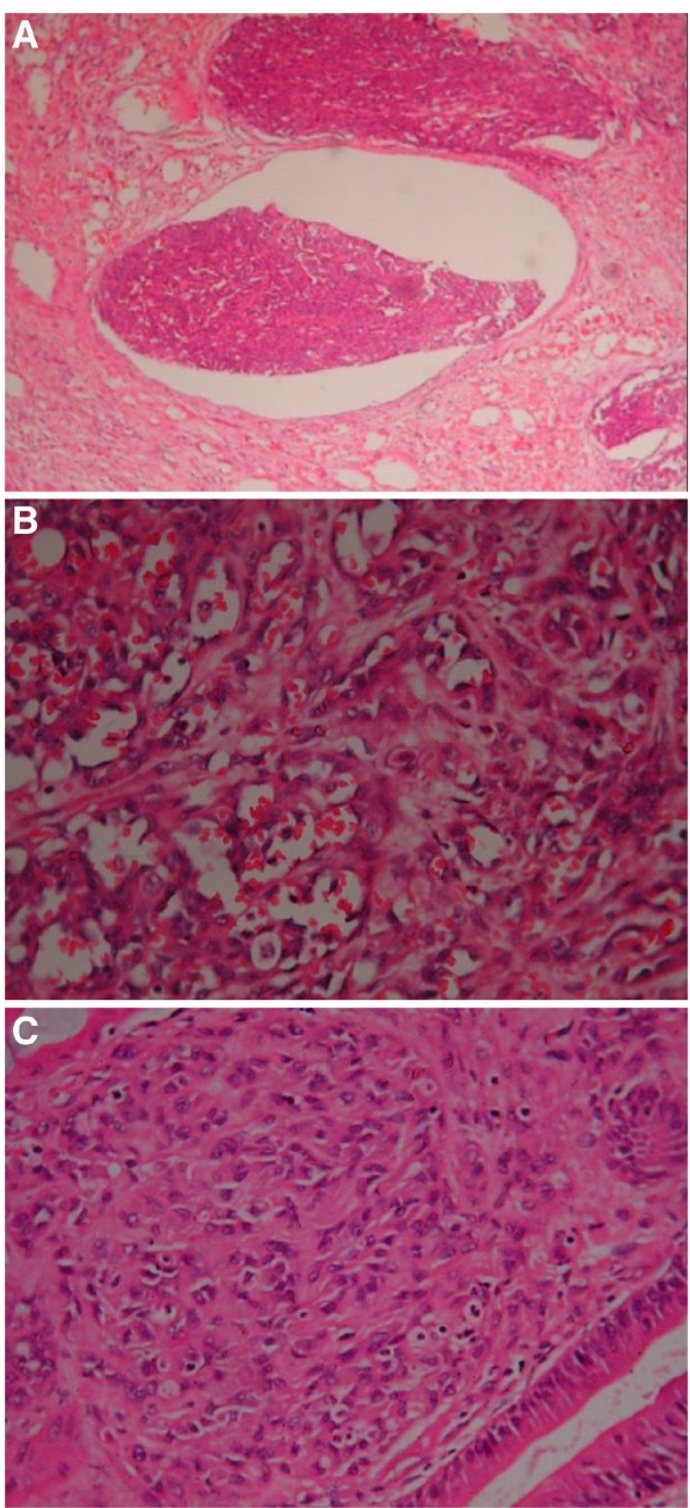

Figure 3 Microscopic examination. (A) Tumour tissue can be observed invading the vascular cavity (hematoxylin and eosin stain; $\times 100$ ). (B) Tumor blood vessels were abundant, with the tumor cells surrounding them (hematoxylin and eosin stain; $\times 400$ ). (C) The tumor cells were arranged in a slit-shaped pattern (hematoxylin and eosin stain; $\times 400$ ).
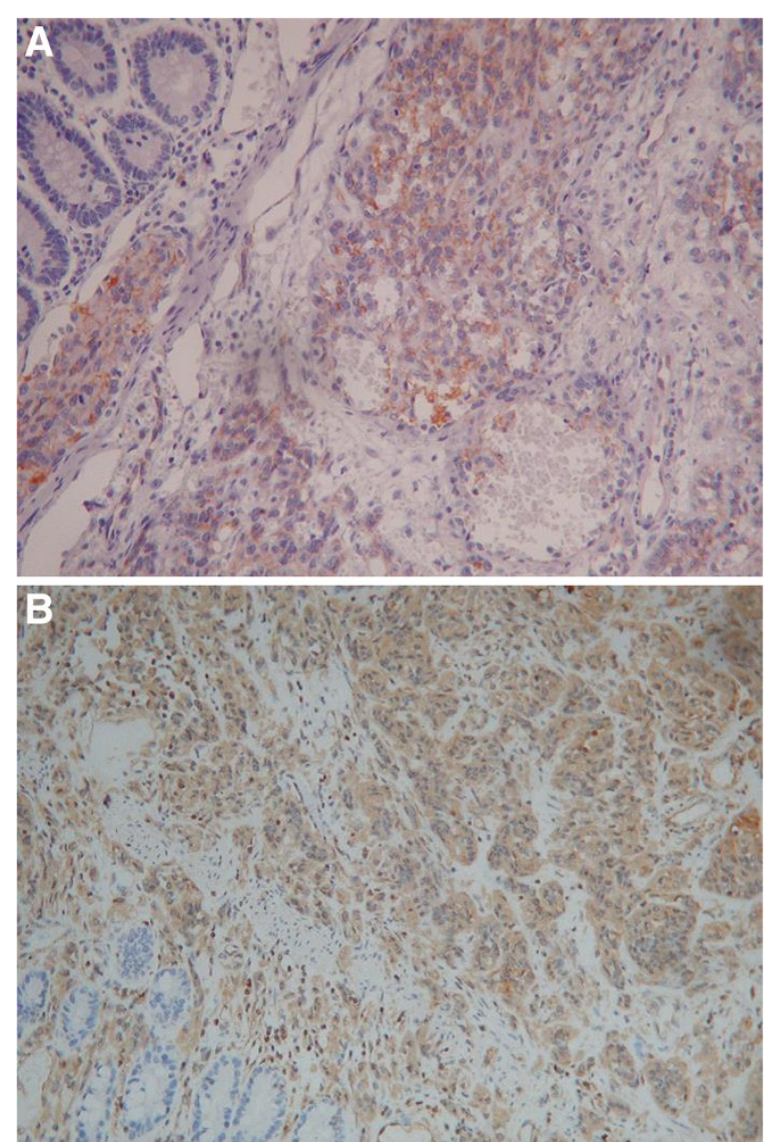

Figure 4 Immunohistochemistry results. The tumor cells were positive for (A) CD31 (hematoxylin and eosin stain; $\times 400$ ) and (B) vimentin (hematoxylin and eosin stain; $\times 200$ ).

disease, gastrointestinal stromal tumor (GIST) and lymphoma were excluded. Hence, the diagnosis of primary angiosarcoma of the small intestine with metastasis to the liver was confirmed.

After surgical resection, the patient was managed with adjuvant chemotherapy and palliative care. Approximately 400 to $500 \mathrm{ml}$ hemorrhagic fluid was drained during the postoperative period through the abdominal drains. Moreover, the volume of hemorrhagic fluid increased to $600 \mathrm{ml}$ on the 6th postoperative day. Therefore, a cytologic

Table 1 Previous data regarding angiosarcoma and small intestinal angiosarcoma in the study population

\begin{tabular}{|c|c|c|c|}
\hline Reference & Study population & $\begin{array}{l}\text { Number of patients } \\
\text { with angiosarcoma }\end{array}$ & $\begin{array}{l}\text { Number of patients with } \\
\text { small intestinal angiosarcoma }\end{array}$ \\
\hline Gentry et al. [8] 1949 & $\begin{array}{l}106 \text { patients with vascular tumors of the gastrointestinal } \\
\text { tract between } 1925 \text { and } 1944 \text {. }\end{array}$ & 16 & 3 \\
\hline Karpeh et al. [9] 1991 & $\begin{array}{l}69 \text { adult patients admitted to the Memorial Sloan-Kettering } \\
\text { Cancer Center between } 1982 \text { and } 1990 .\end{array}$ & 35 & $\leq 10$ \\
\hline Naka et al. [3] 1995 & 99 Japanese patients with angiosarcoma between 1974 and 1990. & 99 & 0 \\
\hline Allison et al. [10] 2004 & $\begin{array}{l}19 \text { previously reported cases of angiosarcoma involving } \\
\text { the gastrointestinal tract between } 1990 \text { and } 2002 \text {. }\end{array}$ & 19 & 8 \\
\hline
\end{tabular}


Table 2 Cases of primary angiosarcoma involving the small intestine reported in the English literature

\begin{tabular}{|c|c|c|c|c|c|c|c|c|}
\hline Authors & $\begin{array}{l}\text { Sex/age } \\
\text { (years) }\end{array}$ & $\begin{array}{l}\text { Primary or } \\
\text { secondary }\end{array}$ & Site & $\begin{array}{l}\text { Immunohistochemical } \\
\text { staining }\end{array}$ & $\begin{array}{l}\text { History of prior } \\
\text { radiation or other } \\
\text { predisposing factor }\end{array}$ & Presentation & Treatment & Follow-up \\
\hline Maeyashiki et al. [11] & $M / 72$ & Indeterminate & Small bowel & $\begin{array}{l}\text { Positive for CD31, CD34 } \\
\text { and factor VIII }\end{array}$ & None & Anemia, melaena & $\begin{array}{l}\text { Resection and daily } \\
\text { blood transfusions }\end{array}$ & $\begin{array}{l}\text { Died on hospital } \\
\text { day } 103\end{array}$ \\
\hline Siderits et al. [12] & $M / 79$ & Primary & Small bowel & $\begin{array}{l}\text { Strongly positive for } \\
\text { CD31 }\end{array}$ & None & Obstruction & Resection & Unknown \\
\hline Taxy and Battifora [13] & $M / 64$ & Primary & Small bowel & $\begin{array}{l}\text { Positive for Factor VIII, } \\
\text { collagen type IV and } \\
\text { vimentin }\end{array}$ & Not available & $\begin{array}{l}\text { Gastrointestinal } \\
\text { bleeding }\end{array}$ & Resection & $\begin{array}{l}\text { Died } 1 \text { year after } \\
\text { the initial diagnosis }\end{array}$ \\
\hline Taxy and Battifora [13] & $F / 57$ & Primary & Small bowel & $\begin{array}{l}\text { Positive for Factor VIII, } \\
\text { collagen type IV }\end{array}$ & Not available & Not available & Resection & $\begin{array}{l}\text { Died shortly after } \\
\text { surgery }\end{array}$ \\
\hline Chami et al. [14] & $M / 59$ & Primary & Small bowel & $\begin{array}{l}\text { Weakly positive for factor } \\
\text { VIII-related antigen, Ulex } \\
\text { europaeus I antigen and } \\
\text { cytokeratin }\end{array}$ & None & $\begin{array}{l}\text { Gastrointestinal bleeding, } \\
\text { bowel obstruction, anorexia } \\
\text { and weight loss }\end{array}$ & $\begin{array}{l}\text { Resection and } \\
\text { transfusions }\end{array}$ & $\begin{array}{l}\text { Died on the } 11 \text { th } \\
\text { day after surgery }\end{array}$ \\
\hline Ordonez et al. [15] & $\mathrm{M} / 80$ & Primary & Small bowel & $\begin{array}{l}\text { Positive immunoreaction } \\
\text { for FVIII-RAG }\end{array}$ & None & $\begin{array}{l}\text { Anemia, undue tiredness } \\
\text { and weakness }\end{array}$ & Resection & $\begin{array}{l}\text { Died on the 20th } \\
\text { postoperative day }\end{array}$ \\
\hline Hwang et al. [16] & $F / 60$ & Primary & Small bowel & $\begin{array}{l}\text { Positive for Ulex } \\
\text { europaeus agglutinin } 1\end{array}$ & History of radiotherapy & Diffuse abdominal pain & Resection & $\begin{array}{l}\text { Died } 2 \text { months } \\
\text { after discharge }\end{array}$ \\
\hline Mohammed et al. [5] & $F / 25$ & Primary & Small bowel & Not available & None & $\begin{array}{l}\text { Intermittent abdominal } \\
\text { pain, weight loss, abdominal } \\
\text { distension, hematemesis } \\
\text { and malaena }\end{array}$ & Resection & $\begin{array}{l}\text { Died on the 11th } \\
\text { day after surgery }\end{array}$ \\
\hline Fraiman et al. [17] & M/85 & Primary & Small bowel & $\begin{array}{l}\text { Strong positivity for } \\
\text { vimentin and CD31; } \\
\text { focal positivity for factor } \\
\text { VIII and CD34 }\end{array}$ & None & $\begin{array}{l}\text { Weight loss, anemia, } \\
\text { weakness and abdominal } \\
\text { pain }\end{array}$ & $\begin{array}{l}\text { Resection and } \\
\text { thalidomide }\end{array}$ & Not available \\
\hline Selk et al. [18] & $\mathrm{M} / 57$ & Primary & Small bowel & Not available & $\begin{array}{l}\text { History of radiation } \\
\text { therapy }\end{array}$ & $\begin{array}{l}\text { Progressive abdominal } \\
\text { distention and shortness } \\
\text { of breath }\end{array}$ & Resection & $\begin{array}{l}\text { Died } 4 \text { months } \\
\text { after surgery }\end{array}$ \\
\hline Berry et al. [19] & $M / 51$ & Primary & Small bowel & $\begin{array}{l}\text { Positive for Ulex } \\
\text { europaeus and vimentin }\end{array}$ & $\begin{array}{l}\text { History of 3-year } \\
\text { irradiation }\end{array}$ & Peritonitis & $\begin{array}{l}\text { Resection, adriamycin } \\
\text { and dacarbazine }\end{array}$ & $\begin{array}{l}\text { Died } 5 \text { months after } \\
\text { initial presentation }\end{array}$ \\
\hline Watanabe et al. [20] & $M / 64$ & Primary & $\begin{array}{l}\text { Duodenum and upper } \\
\text { jejunum }\end{array}$ & $\begin{array}{l}\text { Positive for vimentin } \\
\text { and anti-endothelin-1 }\end{array}$ & Not available & $\begin{array}{l}\text { Persistent gastrointestinal } \\
\text { bleeding }\end{array}$ & Not available & $\begin{array}{l}\text { Died of pulmonary } \\
\text { metastasis } 1 \text { year } \\
\text { after the operation }\end{array}$ \\
\hline Al Ali et al. [1] & $M / 87$ & Indeterminate & Small bowel & Positive for CD31 & None & $\begin{array}{l}\text { Lethargy, weakness and } \\
\text { anemia }\end{array}$ & Resection & $\begin{array}{l}\text { Died } 6 \text { weeks after } \\
\text { the initial diagnosis }\end{array}$ \\
\hline Khalil et al. [21] & $M / 68$ & Primary & Small bowel & $\begin{array}{l}\text { Strongly positive for } \\
\text { CD31, CD34 and } \\
\text { vimentin }\end{array}$ & $\begin{array}{l}30 \text { year history of heavy } \\
\text { occupational exposure } \\
\text { to radiation and polyvinyl } \\
\text { chloride }\end{array}$ & $\begin{array}{l}\text { Gastrointestinal bleeding } \\
\text { and melaena }\end{array}$ & Resection & $\begin{array}{l}\text { Died } 6 \text { months after } \\
\text { initial presentation }\end{array}$ \\
\hline Suzuki et al. [22] & $F / 61$ & Primary & Ileum & $\begin{array}{l}\text { Positive for factor } \\
\text { VIII-related antigen } \\
\text { and Ulex europaeus } \\
\text { agglutinin } 1\end{array}$ & $\begin{array}{l}20 \text { year history of } \\
\text { radiotherapy }\end{array}$ & Abdominal pain & $\begin{array}{l}\text { Resection and intra- } \\
\text { abdominal cisplatin }\end{array}$ & $\begin{array}{l}\text { Died } 1 \text { year after } \\
\text { initial presentation }\end{array}$ \\
\hline
\end{tabular}


Table 2 Cases of primary angiosarcoma involving the small intestine reported in the English literature (Continued)

\begin{tabular}{|c|c|c|c|c|c|c|c|c|}
\hline Cilursu [23] & $F / 74$ & Indeterminate & Small bowel & Not available & Not available & Melaena & Resection & Not available \\
\hline Delvaux et al. [24] & M/67 & Primary & Small bowel & $\begin{array}{l}\text { Positive for CD 31, } \\
\text { CD 34, factor VIII-related } \\
\text { antigen and keratin }\end{array}$ & Not available & $\begin{array}{l}\text { Weight loss, intermittent } \\
\text { severe abdominal pain } \\
\text { and melaena }\end{array}$ & Resection & $\begin{array}{l}\text { Died } 3 \text { months } \\
\text { after diagnosis }\end{array}$ \\
\hline Policarpio-Nicolas et al. [25] & $F / 51$ & Primary & Small bowel & $\begin{array}{l}\text { Positive for CD 31, CD } 34 \\
\text { and factor VIII-related } \\
\text { antigen }\end{array}$ & History of irradiation & Abdominal pain & Resection & $\begin{array}{l}\text { Died } 10 \text { months } \\
\text { after laparotomy }\end{array}$ \\
\hline Hansen et al. [26] & $F / 76$ & Primary & Small bowel & $\begin{array}{l}\text { Positive for factor VIII and } \\
\text { vimentin }\end{array}$ & History of irradiation & $\begin{array}{l}\text { Watery diarrhea, vomiting, } \\
\text { weight loss and abdominal } \\
\text { pain }\end{array}$ & Resection & $\begin{array}{l}\text { Died } 5 \text { months } \\
\text { after operation }\end{array}$ \\
\hline Aitola et al. [27] & $\mathrm{F} / 50$ & Primary & Small bowel & $\begin{array}{l}\text { Positive for CD 31, CD } 34 \\
\text { and factor VIII-related } \\
\text { antigen }\end{array}$ & $\begin{array}{l}\geq 10 \text { year history of } \\
\text { radiotherapy }\end{array}$ & Intestinal obstruction & $\begin{array}{l}\text { Resection followed } \\
\text { by combination } \\
\text { chemotherapy with } \\
\text { doxorubicin }\end{array}$ & $\begin{array}{l}1 \text { year and } 9 \\
\text { months after } \\
\text { diagnosis, she } \\
\text { was alive }\end{array}$ \\
\hline Aitola et al. [27] & $F / 78$ & Primary & Jejunum & $\begin{array}{l}\text { Positive for factor } \\
\text { VIII-related antigen, CD31, } \\
\text { CD34 and Ulex europaeus }\end{array}$ & $\begin{array}{l}\geq 10 \text { year history of } \\
\text { radiotherapy }\end{array}$ & Intestinal obstruction & Resection & $\begin{array}{l}\text { Died of sepsis } \\
2 \text { years after } \\
\text { diagnosis }\end{array}$ \\
\hline Knop et al. [28] & $M / 72$ & Primary & Small bowel & Not available & Not available & $\begin{array}{l}\text { Gastrointestinal bleeding } \\
\text { and anemia }\end{array}$ & Resection & Not available \\
\hline Ogawa et al. [29] & $M / 36$ & Primary & Small bowel & $\begin{array}{l}\text { Positive for factor } \\
\text { VIII-related antigen }\end{array}$ & Not available & $\begin{array}{l}\text { Abdominal pain and } \\
\text { nausea }\end{array}$ & Surgical treatment & Not available \\
\hline $\begin{array}{l}\text { de Mascarenhas- } \\
\text { Saraiva et al. [30] }\end{array}$ & M/82 & Primary & lleum & Not available & Not available & $\begin{array}{l}\text { Melaena and increasing } \\
\text { shortness of breath }\end{array}$ & $\begin{array}{l}\text { Surgical treatment } \\
\text { and transfusions }\end{array}$ & Not available \\
\hline Turan et al. [31] & Not available & Indeterminate & Jejunum & Not available & Not available & Acute abdominal signs & $\begin{array}{l}\text { Resection and } \\
\text { chemotherapy }\end{array}$ & Not available \\
\hline Liu et al. [32] & $F / 39$ & Primary & Terminal ileum & $\begin{array}{l}\text { Positive for CD31 } \\
\text { and CD34 }\end{array}$ & None & $\begin{array}{l}\text { Increasing right iliac fossa } \\
\text { pain, abdominal bloating } \\
\text { and vomiting }\end{array}$ & $\begin{array}{l}\text { Resection and } \\
\text { chemotherapy }\end{array}$ & Not available \\
\hline Kelemen et al. [33] & $M / 76$ & Primary & Small bowel & Positive for CD31 & None & $\begin{array}{l}\text { Abdominal pain and } \\
\text { fatigue }\end{array}$ & Resection & $\begin{array}{l}\text { Died of cardiac } \\
\text { arrest on the 9th } \\
\text { day after surgery }\end{array}$ \\
\hline Fohrding et al. [34] & $\mathrm{M} / 84$ & Primary & Small bowel & $\begin{array}{l}\text { Positive for CD31, } \\
\text { cytokeratin and vimentin; } \\
\text { slightly weaker for CD34; } \\
\text { Focally positive for } \\
\text { factor VIII }\end{array}$ & Not available & Gastrointestinal bleeding & $\begin{array}{l}\text { Resection, adjuvant } \\
\text { chemotherapy with } \\
\text { paclitaxel and } \\
\text { transfusion }\end{array}$ & Not available \\
\hline Grewal et al. [35] & $M / 73$ & Primary & Small bowel & Positive for CD31 & None & $\begin{array}{l}\text { Gastrointestinal bleeding, } \\
\text { weakness and melaena }\end{array}$ & Resection & $\begin{array}{l}\text { Died within } 4 \\
\text { months of the } \\
\text { diagnosis }\end{array}$ \\
\hline M, male; F, female & & & & & & & & \\
\hline
\end{tabular}


examination was performed, which showed malignant cells, confirming the diagnosis of malignant ascites. The patient received frequent blood transfusions due to a progressive drop in hemoglobin. In the early morning hours of the 27th postoperative day, the patient experienced a sudden disturbance of consciousness along with a progressive decrease in blood pressure. Due to the above-mentioned circumstances, further treatment was refused by the patient's relatives. The patient died on the morning of the 27 th postoperative day.

\section{Discussion}

Angiosarcoma, a malignant neoplasm derived from the endothelial cells of blood vessels or lymphatic vessels, is characterized by aggressively proliferating and widely distributed tumor cells [6].

In 1879, Langhans and colleagues reported the first angiosarcoma in the spleen [7]. Thereafter, only a few cases of primary angiosarcoma involving the small intestine have been reported. Gentry and colleagues reviewed 106 vascular tumors of the gastrointestinal tract at the Mayo Clinic between 1925 and 1944, among which 16 angiosarcomas were found; furthermore, only three involved the small intestine [8]. Karpeh and colleagues reviewed 69 adult patients admitted to the Memorial Sloan-Kettering Cancer Center between 1982 and 1990. In this study, 35 angiosarcomas were found, and only 10 involved the viscus or retroperitoneum [9]. Naka and colleagues reviewed 99 Japanese patients with angiosarcoma diagnosed between 1974 and 1990, and no small intestinal angiosarcomas were found [3]. Allison and colleagues reviewed the cases of angiosarcoma that were diagnosed from 1990 to 2002 at the University of Washington and the Cleveland Clinic Foundation, finding only eight cases of angiosarcoma involving the gastrointestinal tract [10] (Table 1).
To gain a deeper understanding of primary angiosarcoma of the small intestine, we searched the PubMed database. The following search terms were used: "hemangiosar coma"[MeSH Terms] OR "hemangiosarcoma"[All Fields] OR "angiosarcoma"[All Fields]) AND ("intestine, small" [MeSH Terms] OR "small intestine"[All Fields] OR "small bowel”[All Fields]) AND (English[Language]). Only 54 eligible articles were retrieved. We excluded articles that described secondary cases and articles describing animal angiosarcoma involving the small intestine. Finally, only 27 articles remained [1,5,11-35] (Table 2).

Only one younger case, a 25-year-old woman, was reported as having primary angiosarcoma of the small intestine with normal liver, spleen, rectum, urinary bladder, kidneys, uterus and adnexae [5]. To our knowledge, there are few reports of primary angiosarcoma of the small intestine with metastasis to the liver among such young patients in the English literature.

Intestinal angiosarcoma often presents with gastrointestinal bleeding, abdominal pain, intestinal obstruction, abdominal distention, weight loss, shortness of breath, anemia and weakness $[5,10]$.

Young and colleagues reviewed angiosarcoma with a focus on clinical trials and outlined its risk factors [2]. According to these authors, the risk factors for angiosarcoma were varied and are listed in Figure 5.

Magnetic resonance imaging (MRI), CT, positron emission tomography (PET), X-rays, ultrasound, endoscopy, immunohistochemical testing and a pathological examination can contribute to the diagnosis of angiosarcoma [2,30,31]. MRI, CT, abdominal X-rays and ultrasound are used to delineate the extent of the lesions in the preoperative period of abdominal angiosarcoma [2,31]. CT and PET may be helpful for detecting metastases in the preoperative period [2]. The lesions and the sources of bleeding can be detected by endoscopy. Meanwhile, endoscopic biopsy can

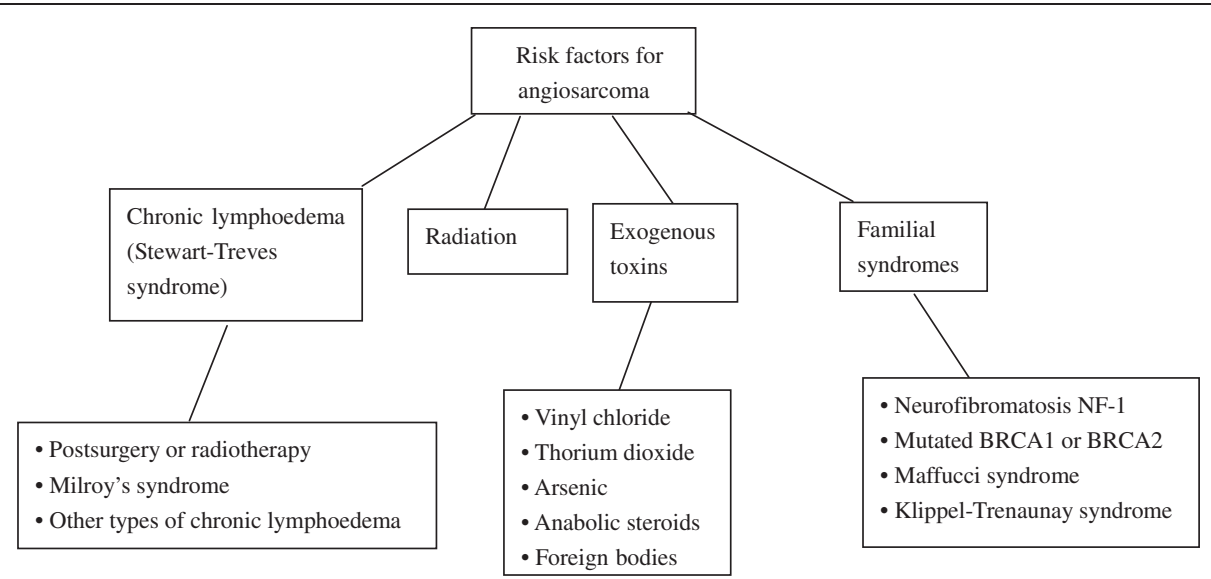

Figure 5 Risk factors for angiosarcoma. 
be performed; significantly, wireless capsule endoscopy is a new endoscopic method that can help to improve the diagnosis of deep small intestinal pathology [30]. Von Willebrand factor, CD34, CD31, Ulex europaeus agglutinin 1, vascular endothelial growth factor, melanocytic markers (such as S100), human melanoma black-45, melanoma antigen and cytokeratins all are useful for diagnosis and differential diagnosis [2]. Moreover, poorly differentiated adenocarcinoma, intestinal tuberculosis, neuroendocrine tumor, malignant melanoma, Crohn's disease, GIST, lymphoma and mesothelioma should be excluded, although with difficulty, in differential diagnosis $[10,33]$. Pathological and immunohistochemical examinations can contribute to the definitive diagnosis of angiosarcoma [21].

Due to the rarity of randomized trials and prospective studies, the management guidelines for other soft tissue sarcomas tend to be utilized when dealing with angiosarcoma [2]. Complete surgical excision tends to be impossible due to the aggressive proliferation and wide metastasis of angiosarcoma [1]. In the current setting, surgical excision associated with adjuvant radiotherapy and/or chemotherapy may be useful; however, the efficacy of these treatments for angiosarcoma remains unclear. Therefore, further studies are desperately needed to determine the optimal treatment for angiosarcoma [1].

Generally speaking, the prognosis of angiosarcoma is very poor. Moreover, several investigators have noted that the site of angiosarcoma tends to affect prognosis [2], and the prognosis of angiosarcoma of the small intestine is significantly worse than that of angiosarcoma at any other site [17]. Indeed, most patients die within a few months of diagnosis, and some die within the postoperative period [17]. Patients with intestinal angiosarcomas who survive over 1 year after diagnosis are extraordinarily rare [14].

\section{Conclusion}

Primary angiosarcoma of the small intestine is an extremely rare and aggressive soft-tissue malignant tumor. The findings of this case report are of extreme significance. To our knowledge, this may be the first report of primary angiosarcoma of the small intestine with metastasis to the liver in such a young patient. In the future, we should focus on similar cases to ensure early diagnosis and proper treatment.

\section{Consent}

Written informed consent was obtained from the patient for publication of this case report and any accompanying images. A copy of the written consent is available for review by the Editor-in-Chief of this journal.

\section{Abbreviations}

CT: Computed tomography; GIST: Gastrointestinal stromal tumor; MRI: Magnetic resonance imaging; PET: Positron emission tomography.
Competing interests

The authors declare that they have no competing interests.

\section{Authors' contributions}

QN searched the database, selected the articles, and wrote the manuscript. DS supervised the methodology, the selection of the articles, and the writing of the manuscript and is the corresponding author of the paper. HP assisted in drafting the manuscript. MR supervised the writing of the manuscript. WB, GL, XG and DS performed the surgeries. All the authors have read and approved the final manuscript.

\section{Acknowledgements}

We thank Prof. Dong Shang for assisting in the preparation of this manuscript.

\section{Author details}

'Department of General Surgery, First Affiliated Hospital, Dalian Medical University, Dalian, Liaoning 116011, P.R. China. ${ }^{2}$ Department of General Surgery, Linyi Economic And Technological Development Zone People's Hospital, Linyi, Shandong 276000, P.R. China. ${ }^{3}$ Department of Surgery, Kathmandu Medical College, 184 Baburam Acharya Sadak, Sinamangal, P.O. Box: 21266, Kathmandu, Nepal. ${ }^{4}$ Department of Pathology, First Affiliated Hospital, Dalian Medical University, Dalian, Liaoning 116011, P.R. China.

Received: 24 April 2013 Accepted: 3 September 2013

Published: 25 September 2013

\section{References}

1. Al Ali J, Ko HH, Owen D, Steinbrecher UP: Epithelioid angiosarcoma of the small bowel. Gastrointest Endosc 2006, 64:1018-1021.

2. Young RJ, Brown NJ, Reed MW, Hughes D, Woll PJ: Angiosarcoma. Lancet Oncol 2010, 11:983-991.

3. Naka N, Ohsawa M, Tomita Y, Kanno H, Uchida A, Aozasa K: Angiosarcoma in Japan. A review of 99 cases. Cancer 1995, 75:989-996.

4. Yoshida K, Ito F, Nakazawa H, Maeda Y, Tomoe H, Aiba M: A case of primary renal angiosarcoma. Rare Tumors 2009, 1:e28.

5. Mohammed A, Aliyu HO, Liman AA, Abdullahi K, Abubakar N: Angiosarcoma of the small intestine. Ann Afr Med 2011, 10:246-248.

6. Antonescu CR: Targeted therapies in gastrointestinal stromal tumors. Semin Diagn Pathol 2008, 25:295-303.

7. Delacruz V, Jorda M, Gomez-Fernandez C, Benedetto P, Ganjei P: Fineneedle aspiration diagnosis of angiosarcoma of the spleen: a case report and review of the literature. Arch Pathol Lab Med 2005, 129:1054-1056.

8. Gentry RW, Dockerty MB, Glagett OT: Vascular malformations and vascular tumors of the gastrointestinal tract. Surg Gynecol Obstet 1949, 88:281-323.

9. Karpeh MS Jr, Caldwell C, Gaynor JJ, Hajdu SI, Brennan MF: Vascular softtissue sarcomas. An analysis of tumor-related mortality. Arch Surg 1991, 126:1474-1481.

10. Allison KH, Yoder BJ, Bronner MP, Goldblum JR, Rubin BP: Angiosarcoma involving the gastrointestinal tract: a series of primary and metastatic cases. Am J Surg Pathol 2004, 28:298-307.

11. Maeyashiki C, Nagata N, Uemura N: Angiosarcoma involving solid organs and the gastrointestinal tract with life-threatening bleeding. Case Rep Gastroenterol 2012, 6:772-777.

12. Siderits R, Poblete F, Saraiya B, Rimmer C, Hazra A, Aye L: Angiosarcoma of small bowel presenting with obstruction: novel observations on a rare diagnostic entity with unique clinical presentation. Case Rep Gastrointest Med 2012, 2012:480135.

13. Taxy JB, Battifora $\mathrm{H}$ : Angiosarcoma of the gastrointestinal tract. A report of three cases. Cancer 1988, 62:210-216.

14. Chami TN, Ratner LE, Henneberry J, Smith DP, Hill G, Katz PO: Angiosarcoma of the small intestine: a case report and literature review. Am J Gastroenterol 1994, 89:797-800.

15. Ordonez NG, del Junco GW, Ayala AG, Ahmed N: Angiosarcoma of the small intestine: an immunoperoxidase study. Am J Gastroenterol 1983, 78:218-221.

16. Hwang TL, Sun CF, Chen MF: Angiosarcoma of the small intestine after radiation therapy: report of a case. J Formos Med Assoc 1993, 92:658-661.

17. Fraiman G, Ganti AK, Potti A, Mehdi S: Angiosarcoma of the small intestine: a possible role for thalidomide? Med Oncol 2003, 20:397-402. 
18. Selk A, Wehrli B, Taylor BM: Chylous ascites secondary to small-bowel angiosarcoma. Can J Surg 2004, 47:383-384.

19. Berry GJ, Anderson CJ, Pitts WC, Neitzel GF, Weiss LM: Cytology of angiosarcoma in effusions. Acta Cytol 1991, 35:538-542.

20. Watanabe K, Hoshi N, Suzuki T: Epithelioid angiosarcoma of the intestinal tract with endothelin-1-like immunoreactivity. Virchows Arch A Pathol Anat Histopathol 1993, 423:309-314.

21. Khalil MF, Thomas A, Aassad A, Rubin M, Taub RN: Epithelioid angiosarcoma of the small intestine after occupational exposure to radiation and polyvinyl chloride: a case report and review of literature. Sarcoma 2005, 9:161-164.

22. Suzuki F, Saito A, Ishi K, Koyatsu J, Maruyama T, Suda K: Intra-abdominal angiosarcomatosis after radiotherapy. J Gastroenterol Hepatol 1999, 14:289-292

23. Cilursu AM: Massive hemorrhage due to angiosarcomatosis diagnosed by intraoperative small bowel endoscopy. Endosc 1991, 23:245.

24. Delvaux V, Sciot R, Neuville B, Moerman P, Peeters M, Filez L, Van Beckevoort D, Ectors N, Geboes K: Multifocal epithelioid angiosarcoma of the small intestine. Virchows Arch 2000, 437:90-94.

25. Policarpio-Nicolas ML, Nicolas MM, Keh P, Laskin WB: Postradiation angiosarcoma of the small intestine: a case report and review of literature. Ann Diagn Pathol 2006, 10:301-305.

26. Hansen SH, Holck S, Flyger H, Tange UB: Radiation-associated angiosarcoma of the small bowel. A case of multiploidy and a fulminant clinical course. Case report. APMIS 1996, 104:891-894.

27. Aitola P, Poutiainen A, Nordback I: Small-bowel angiosarcoma after pelvic irradiation: a report of two cases. Int J Colorectal Dis 1999, 14:308-310.

28. Knop FK, Hansen MB, Meisner S: Small-bowel hemangiosarcoma and capsule endoscopy. Endosc 2003, 35:637.

29. Ogawa S, Minowa O, Ozaki Y, Kuwatsuru R, Sumi Y, Maehara T: Small bowel intussusception caused by intestinal angiosarcomatosis: usefulness of MR enteroclysis with infusion of water through a nasojejunal catheter. Eur Radiol 2002, 12:534-536.

30. de Mascarenhas-Saraiva MN, da Silva Araujo Lopes LM: Small-bowel tumors diagnosed by wireless capsule endoscopy: report of five cases. Endosc 2003, 35:865-868.

31. Turan M, Karadayi K, Duman M, Ozer H, Arici S, Yildirir C, Kocak O, Sen M: Small bowel tumors in emergency surgery. Ulus Travma Acil Cerrahi Derg 2010, 16:327-333.

32. Liu DS, Smith H, Lee MM, Djeric M: Small intestinal angiosarcoma masquerading as an appendiceal abscess. Ann R Coll Surg Engl 2013, 95:e22-e24.

33. Kelemen $\mathrm{K}$, Yu QQ, Howard L: Small intestinal angiosarcoma leading to perforation and acute abdomen: a case report and review of the literature. Arch Pathol Lab Med 2004, 128:95-98.

34. Zacarias Fohrding L, Macher A, Braunstein S, Knoefel WT, Topp SA: Small intestine bleeding due to multifocal angiosarcoma. World I Gastroenterol 2012, 18:6494-6500.

35. Grewal JS, Daniel AR, Carson EJ, Catanzaro AT, Shehab TM, Tworek JA: Rapidly progressive metastatic multicentric epithelioid angiosarcoma of the small bowel: a case report and a review of literature. Int J Colorectal Dis 2008, 23:745-756.

doi:10.1186/1477-7819-11-242

Cite this article as: Ni et al:: Primary angiosarcoma of the small intestine with metastasis to the liver: a case report and review of the literature. World Journal of Surgical Oncology 2013 11:242.

\section{Submit your next manuscript to BioMed Central and take full advantage of:}

- Convenient online submission

- Thorough peer review

- No space constraints or color figure charges

- Immediate publication on acceptance

- Inclusion in PubMed, CAS, Scopus and Google Scholar

- Research which is freely available for redistribution

Submit your manuscript at www.biomedcentral.com/submit
Biomed Central 